\title{
Peningkatan Aktivitas Dan Hasil Belajar IPS Melalui Model Pembelajaran Kooperatif Tipe Jigsaw Siswa SMP Negeri 1 Kubu
}

\author{
I Gede Suparta ${ }^{1 *}$, I Gede Astra Wesnawa ${ }^{1}$, I Putu Sriartha ${ }^{1}$
}

1Program Studi Pendidikan Geografi, Jurusan Geografi, Universitas Pendidikan Ganesha, Indonesia

\author{
A R T I C L EI N F O \\ Article history: \\ Received \\ Received in revised \\ form \\ Accepted \\ Available online \\ Kata Kunci: \\ Aktivitas Belajar; Hasil \\ Belajar; Jigsaw \\ Keywords: \\ Learning Activities; \\ Learning Outcomes; \\ Jigsaw
}

\begin{abstract}
A B S T R A K
Penelitian ini bertujuan untuk menganalisis penerapan model pembelajaran kooperatif tipe Jigsaw diaplikasikan dalam pembelajaran IPS, peningkatan aktivitas belajar siswa, dan peningkatan hasil belajar IPS siswa kelas VII H di SMP N 1 Kubu. Penelitian ini didesain dalam bentuk Penelitian Tindakan Kelas (PTK) yang dilakukan dalam bentuk siklus. Setiap siklus terdiri dari empat tahap (perencanaan, pelaksanaan, observasi dan refleksi). Sasaran perbaikan terdiri dari 30 orang siswa yang dilakukan oleh guru kelas VII H SMP N 1 Kubu, data dikumpulkan dengan teknik observasi, tes dan dokumentasi yang dianalisis dengan menggunakan teknik analisis deskriptif kualitatif. Data yang dianalisis yakni data pembelajaran oleh guru, aktivitas belajar dan hasil belajar siswa. Hasil penelitian menunjukkan bahwa penerapan model pembelajaran kooperatif tipe Jigsaw dapat diaplikasikan oleh guru IPS dengan rata-rata nilai meningkat dari 72 dengan kategori baik pada siklus I menjadi 92 dengan kategori amat baik pada siklus II. Penerapan model pembelajaran kooperatif
\end{abstract} tipe Jigsaw dapat meningkatkan aktivitas belajar IPS siswa dengan nilai rata-rata meningkat dari 79,08 dengan kategori cukup pada siklus I menjadi 87,38 dengan kategori aktif pada siklus II. Penerapan model pembelajaran kooperatif tipe Jigsaw dapat meningkatkan hasil belajar IPS siswa kelas VII H SMP Negeri 1 Kubu dengan rata-rata hasil belajar siswa meningkat dari 60,00 menjadi 81,17. Dengan menerapkan model pembelajaran kooperatif tipe Jigsaw dalam pembelajaran IPS di kelas VII H dapat meningkatkan aktivitas belajar dan hasil belajar siswa serta dapat merubah suasana belajar lebih efektif, menyebabkan siswa menjadi lebih aktif mencari dan menggali berbagai informasi mengenai materi yang dijelaskan.

\begin{abstract}
A B S T R A C T
This study aims to analyze the application of Jigsaw type of cooperative learning models applied in learning social studies, the improvement of student's social learning, the improvement of social studies learning outcomes of students of class VII H in SMP N 1 Kubu. The study was designed in the set of Classroom Action Research (CAR) in which was conducted in the cycles. Each cycle consisted of four stages (planning, implementation, observation and reflection). The target of improvement consisted of 30 students conducted by VII H grade teachers of SMP N 1 Kubu data were collected through observation, tests and documentation techniques which were analyzed using descriptive analysis techniques qualitative. The results showed that the application of the Jigsaw cooperative learning model can be applied by social studies teachers with an average value increasing from 72 with good categories in cycle I to 92 with very good categories in cycle II. Application of cooperative learning models. Type of Jigsaw could increase student's social studies learning activities with an average value increasing from 79.08 with enough categories in cycle I to 87.38 with active categories in cycle II. The application of Jigsaw cooperative learning models can improve student's social learning outcomes Grade VII H of SMP Negeri 1 Kubu with an average student learning outcome increasing from 60.00 to 81.17. by applying the model cooperative learning type jigsaw in learning IPS in class VII $\mathrm{H}$ can increase learning activities and student learning outcomes and can change the atmosphere learn more effective, causing students become more actively looking for and dig a variety of information on the material described.
\end{abstract}





\section{Pendahuluan}

Pendidikan mempunyai peranan yang sangat penting bagi suatu negara untuk memajukan negaranya agar dapat bersaing dengan negara lain. Kemajuan suatu negara sangat didukung oleh kualitas SDM yang dimiliki dan untuk menciptakannya dipersiapkan melalui proses pendidikan. Pendidikan adalah humanisasi, yaitu upaya memanusiakan manusia atau upaya membantu manusia agar mampu mewujudkan diri sesuai dengan martabat kemanusiaannya (Wahyudin, 2007: 11). Pendidikan tidak lagi berpegang pada paradigma lama bahwa ilmu diperoleh dengan jalan diberikan atau diajarkan oleh guru kepada siswa. Selain itu guru secara kuantitas maupun kualitas kurang memadai terutama untuk sekolah di daerah terpencil, dan dalam mengajar tidak sesuai antara ilmu yang dipelajari dengan mata pelajaran yang diajarkan (Munirah, 2015: 238). Hal tersebut berdampak pada aktivitas dan hasil belajar siswa di sekolah. Aktivitas dan hasil belajar siswa sangat ditentukan oleh guru dan strategi pembelajaran yang diterapkan guru masing-masing pengampu mata pelajaran di sekolah.

Berdasarkan hal tersebut, peran guru dalam memilih model pembelajaran yang diterapkan dalam proses pembelajaran mempengaruhi aktivitas dan hasil belajar. Menurut Apriliawati, (2011) aktivitas belajar adalah kegiatan yang dilakukan siswa selama proses pembelajaran. Aktivitas siswa selama pembelajaran mencerminkan adanya motivasi ataupun keinginan siswa untuk belajar. Sementara hasil belajar menurut Moedjiono dan Moh Dimyati (1992) adalah hasil dari interaksi tindak belajar murid dan tindak mengajar yang dilakukan oleh guru. Tindak mengajar diakhiri dengan proses evaluasi, sedang tindak belajar merupakan puncak dari proses belajar dengan meningkatnya kemampuan.

SMP N 1 Kubu merupakan salah satu SMP yang terletak di Kecamatan Kubu, Kabupaten Karangasem, Bali. Kepala sekolah SMP N 1 Kubu adalah Bapak I Ketut Cakra, S.Pd., M.Pd dengan jumlah siswa sebanyak 891 orang dan guru sebanyak 43 orang. Berdasarkan observasi yang dilakukan pada kelas VII evaluasi hasil belajar siswanya tergolong dalam nilai rata-rata masih kurang. Pada saat proses pembelajaran berlangsung, aktivitas belajar siswa kelas VII H terlihat kurang. Hal ini terlihat ketika guru memberikan pertanyaan pada saat mengajar ataupun diakhir pemberian materi, siswa tidak aktif untuk menjawab. Selain itu diakhir pemberian materi, siswa tidak ada yang mengambil kesempatan untuk bertanya baik kepada guru ataupun kepada siswa lain. Ketika guru menjelaskan materi, beberapa siswa tidak giat menulis point-point yang disampaikan oleh guru.

Upaya yang sudah dilakukan guru IPS di SMP N 1 Kubu kepada siswa kelas VII H dalam mengatasi masalah siswa yang kurang memiliki minat dalam mata pelajaran IPS adalah dengan melaksanakan pendekatan kepada siswa, melakukan kegiatan tanya jawab, memberikan apresiasi pada peserta didik yang aktif menjawab. Namun upaya yang dilakukan belum sepenuhnya dapat mengatasi permasalahan yang telah dikemukakan tersebut. Hal ini dapat dibuktikan dengan rata-rata nilai ulangan IPS kelas VII H yang paling rendah diantara kelas VII lainnya. Untuk lebih jelasnya dapat dilihat pada tabel 1.

Tabel 1. Rata-rata Nilai Ulangan IPS Kelas VII

\begin{tabular}{lll}
\hline Kelas & Rata-rata Nilai Ulangan Semester 1 & KKM \\
\hline VII A & 80 & 68 \\
\hline VII B & 75 & 68 \\
\hline VII C & 65 & 68 \\
\hline VII D & 64 & 68 \\
\hline VII E & 68 & 68 \\
\hline VII F & 74 & 68 \\
\hline VII G & 71 & 68 \\
\hline VII H & 60 & 68 \\
\hline VII I & 65 & 68 \\
\hline
\end{tabular}

(Sumber: SMP N 1 Kubu)

Berdasarkan permasalahan pembelajaran IPS yang terjadi di kelas VII H SMP N 1 Kubu, perlu adanya model pembelajaran yang tepat untuk meningkatkan aktivitas belajar dan hasil belajar siswa dalam pembelajaran. Salah satu model pembelajaran yang dapat digunakan untuk pembelajaran IPS adalah model pembelajaran kooperatif tipe Jigsaw. Menurut Trisianawati (2016: 53) kelebihan model pembelajaran kooperatif tipe Jigsaw diantaranya: 1) Siswa lebih aktif, saling memberikan pendapat serta saling berkompetisi untuk mencapai prestasi yang baik; 2) Siswa lebih memiliki kesempatan berinteraksi sosial dengan temannya; 3) Siswa lebih kreatif dan memiliki tanggung jawab secara individual.

Berdasarkan uraian di atas, dilakukan penelitian untuk menguji penerapan model pembelajaran kooperatif tipe Jigsaw terhadap aktivitas dan hasil belajar IPS yang dilakukan melalui Penelitian Tindakan 
Kelas (PTK) Kolaboratif. Menurut Suhardjono (2008: 63) mengemukakan bahwa dalam pelaksanaan PTK, kerja sama (kolaborasi) antara guru dengan peneliti menjadi hal sangat penting. Melalui kerjasama, mereka secara bersama menggali dan mengkaji permasalahan nyata yang dihadapi guru dan/atau peserta didik di sekolah. Penelitian dirancang secara Kolaboratif antara guru dan peneliti dengan judul "Penerapan Model Pembelajaran Kooperatif Tipe Jigsaw Untuk Meningkatkan Aktivitas dan Hasil Belajar IPS Siswa SMP Negeri $1 \mathrm{Kubu}$ ". Tujuan dari penelitian ini adalah untuk menganalisis tentang (1) model pembelajaran kooperatif tipe Jigsaw diaplikasikan dalam pembelajaran IPS, (2) peningkatan aktivitas belajar siswa, (3) peningkatan hasil belajar IPS siswa kelas VII H di SMP N 1 Kubu.

\section{Metode}

Jenis penelitian ini adalah Penelitian Tindakan Kelas. Peneliti dalam PTK bertindak sebagai partner guru yang dilakukan secara kolaboratif dengan guru IPS di SMP N 1 Kubu dalam menyususn perencanaan pembelajaran yang diterapkan guru dalam pembelajaran IPS di kelas. Pada saat proses belajar mengajar berlangsung peneliti bertindak sebagai observer sementara pada saat refleksi melibatkan peneliti dan guru secara kolaboratif. Data dikumpulkan dengan teknik observasi, tes dan dokumentasi yang dianalisis dengan menggunakan teknik analisis deskriptif kualitatif. Data yang dianalisis yakni data pembelajaran oleh guru, aktivitas belajar dan hasil belajar siswa.

Penelitian ini menggunakan model Kemmis dan McTaggart (dalam Arikunto, 1993: 16). Pelaksanaan setiap siklus terdiri dari empat tahap, yaitu (1) menyusun rencana tindakan, (2) melaksanakan tindakan, (3) melakukan observasi, (4) melaksanakan refleksi. Alur penelitian ini terdiri dari 2 Siklus. Siklus I guru melakukan tatap muka dengan siswa sebanyak 4 kali. Siklus I terdiri dari 4 tahap, yaitu: Tahap perencanaan, tahap pelaksanaan, tahap observasi, tahap refleksi. Siklus II peneliti melakukan tatap muka dengan siswa sebanyak 4 kali. Siklus II terdiri dari 4 tahap, yaitu: Tahap perencanaan, tahap pelaksanaan, tahap observasi, tahap refleksi.

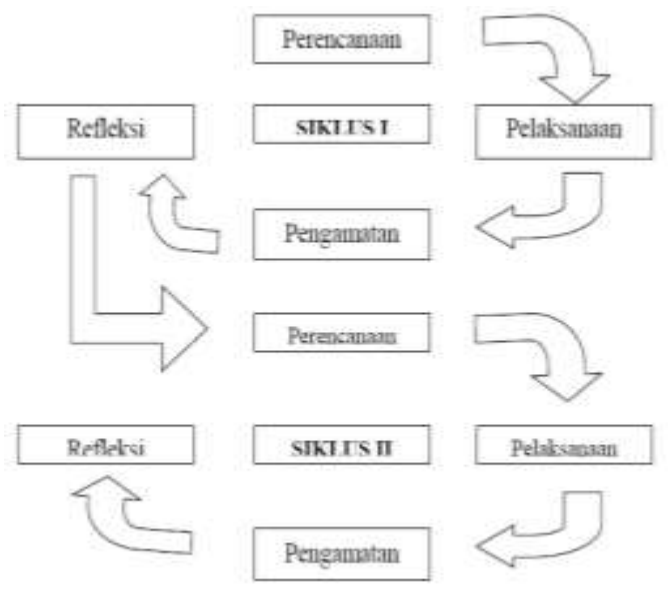

Gambar 1. Alur Penelitian

Alur penelitian ini terdiri dari 2 Siklus. Siklus I guru melakukan tatap muka dengan siswa sebanyak 4 kali yang dilaksanakan pada tanggal 15, 18, 22, dan 25 April 2019. Siklus I terdiri dari 4 tahap, yaitu:

1) Tahap Perencanaan

Tahap ini adalah tahap menyusun rencana tindakan yang akan dilakukan sebagai acuan utama dalam memberikan tindakan di dalam kelas. Peneliti dan guru mata pelajaran IPS di kelas VII H bekerjasama menyusun rencana tindakan sebagai berikut.

a) Peneliti mendiskusikan model pembelajaran kooperatif tipe Jigsaw bersama guru IPS di SMP N 1 Kubu.

b) Menganalisis silabus yang meliputi kompetensi inti, kompetensi dasar, analisis indikator, dan standar penilaian yang akan dipelajari siswa pada siklus I.

c) Merumuskan indikator ketercapaian belajar siswa selama pembelajaran berdasarkan kompetensi dasar yang tertuang dalam silabus. 
d) Menyusun perangkat pembelajaran dan instrumen yang terdiri dari rencana pelaksanaan pembelajaran (RPP), merancang strategi penerapan model Jigsaw, lembar kerja siswa (LKS), tes hasil belajar, angket aktivitas belajar, dan rubik penilaian.

e) Menyiapkan kunci jawaban tes yang akan digunakan dalam penelitian.

2) Tahap Pelaksanaan

Pada tahap ini guru menjelaskan model pembelajaran kooperatif tipe Jigsaw, membentuk kelompok untuk melakukan diskusi, guru menyampaikan standar kompetensi, kompetensi dasar, pengalaman belajar, indikator, serta tujuan pelajaran pada Siklus I. Hal ini dilakukan untuk menggali kemampuan siswa dan siswa mempunyai cukup materi. Membentuk kelompok siswa yang bersifat heterogen.

3) Tahap Observasi

Selama melaksanakan siklus I, peneliti melakukan observasi terhadap pelaksanaan siklus I. Adapun hal-hal yang diobservasi adalah sebagai berikut.

a) Mengobservasi proses pembelajaran yang dilaksanakan pada setiap pertemuan. Hasil observasi pada satu pertemuan menjadi bahan refleksi untuk pertemuan berikutnya sebagai upaya perbaikan.

b) Mencatat kendala-kendala dan permasalahan yang mungkin muncul pada setiap pertemuan.

4) Tahap Refleksi

Refleksi dilaksanakan oleh guru dan peneliti disetiap akhir pertemuan dan akhir siklus I. Refleksi dilaksanakan pada jalannya pembelajaran di kelas dengan tindakan yang diberikan, kendala-kendala yang dialami selama pelaksanaan tindakan, aktivitas siswa dalam pembelajaran ketika tindakan diberlakukan, serta kekurangan-kekurangan yang terdapat pada perangkat pembelajaran. Hasil refleksi pada siklus I dipergunakan sebagai acuan dalam menyusun perencanaan siklus II.

\section{Siklus II}

Siklus II dilakukan berlandaskan hasil siklus I. Guru melakukan tatap muka dengan siswa sebanyak 4 kali yang dilaksanakan pada tanggal 29 April, 2 Mei, 6 Mei, dan 9 Mei 2019. Siklus II terdiri dari 4 tahap, yaitu:

1) Tahap perencanaan

Tahapan perencanaan merupakan serangkaian perencanaan yang dilakukan untuk dapat melaksanakan tindakan pada siklus II. Perencanaan yang dilakukan untuk melaksanakan siklus II adalah sebagai berikut.

a) Menganalisis hasil refleksi siklus I untuk menanggulangi kekurangan-kekurangan yang masih terdapat pada siklus I.

b) Menganalisis silabus yang meliputi kompetensi inti, kompetensi dasar, analisis indikator, dan standar penilaian yang akan dipelajari siswa pada siklus II.

c) Merumuskan indikator ketercapaian belajar siswa selama pembelajaran berdasarkan kompetensi dasar yang tertuang dalam silabus.

d) Menyusun perangkat pembelajaran dan instrumen yang terdiri dari rencana pelaksanaan pembelajaran (RPP), merancang strategi penerapan model Jigsaw, lembar kerja siswa (LKS), tes hasil belajar, angket aktivitas belajar dan rubik penilaian.

2) Tahap Pelaksanaan

Guru memberikan post tes kepada siswa untuk mengetahui sejauh mana kemampuan siswa terhadap materi pembelajaran. Pembelajaran diakhiri dengan evaluasi.

3) Tahap Observasi

Selama melaksanakan siklus yang ke II peneliti melaksanakan observasi. Adapun beberapa hal yang diobservasi dalam pelaksanaan siklus II adalah sebagai berikut.

a) Mengobservasi pelaksanaan tindakan disetiap pertemuan guna mengetahui kekurangannya dan sebagai upaya perbaikan dipertemuan berikutnya. Observasi pada setiap pertemuan juga menjadi tolak ukur terlaksananya tindakan di dalam kelas. Observasi dapat memberikan gambaran aktivitas siswa dalam penyelidikan kelompok. Hasil observasi yang dilaksanakan setiap pertemuan dijadikan sebagai bahan refleksi untuk pertemuan berikutnya.

b) Mencatat kendala-kendala dan permasalahan yang dialami selama pelaksanaan tindakan setiap pertemuan.

4) Tahap Refleksi

Refleksi pada siklus II dilaksanakan oleh guru dan peneliti disetiap akhir pembelajaran dan pada akhir siklus II. Refleksi pada setiap akhir pembelajaran untuk mengidentifikasi kendala-kendala dan kekurangan yang terdapat pada proses pembelajaran. Tindaklanjut diberlakukan untuk mengatasi kendala-kendala dan kekurangan tersebut pada pembelajaran berikutnya. Refleksi pada akhir siklus II 
mengkaji tentang hasil angket aktivitas belajar dan tes hasil belajar serta hambatan dari tindakan yang diberikan pada siklus II. Hasil refleksi pada akhir siklus II merupakan refleksi akhir untuk merumuskan hasil dari semua tindakan yang dilakukan dalam penelitian ini.

Objek penelitian ini adalah aktivitas dan hasil belajar siswa dalam pembelajaran IPS di SMP N 1 Kubu dengan menggunakan model pembelajaran kooperatif tipe Jigsaw. Subjek penelitian adalah siswasiswi kelas VII H di SMP N 1 Kubu. Jenis data dalam penelitian ini terbagi menjadi dua, yaitu data primer dan data sekunder. Data primer merupakan data yang diperoleh melalui observasi dan tes. Data yang dimaksud adalah 1) Pembelajaran oleh guru, 2) aktivitas belajar, 3) hasil belajar IPS siswa kelas VII H yang dibutirkan dalam instrument penelitian berupa kuisioner dengan variabel dan indikator yang telah ditentukan. Data sekunder diperoleh melalui metode pencatatan dokumen. Data yang dimaksud adalah keadaan SMP N I Kubu dan nilai rata-rata ulangan siswa kelas VII H di SMP N 1 Kubu.

Data pembelajaran oleh guru diperoleh dari APKCG. Pedoman penggolongan pembelajaran oleh guru pada model pembelajaran kooperatif tipe Jigsaw dalam pembelajaran IPS dinyatakan dengan Tabel 2 sebagai berikut.

Tabel 2. Kriteria Penggolongan APKCG

\begin{tabular}{|c|c|}
\hline SKOR & Kualifikasi \\
\hline $85-100$ & Amat baik \\
\hline $70-84$ & Baik \\
\hline $55-69$ & Cukup \\
\hline $40-54$ & Kurang \\
\hline $1-39$ & Sangat kurang \\
\hline
\end{tabular}

Rumus :

$$
\frac{\Sigma \mathrm{X} 0}{\Sigma \mathrm{Xi}} \times 100
$$

Dimana :

$\Sigma \mathrm{X}_{0} \quad=$ Jumlah Skor

$\sum \mathrm{Xi} \quad=$ Skor Maksimal Ideal

Kriteria keberhasilan APKCG dikatakan berhasil jika berada pada kategori baik yaitu 70-84.

Data aktivitas belajar menggunakan penilaian acuan patokan (PAP) membandingkan skor yang diperoleh peserta didik dengan suatu standar atau norma absolut. Nilai yang diperoleh siswa pada akhir siklus dirata-ratakan kemudian diubah dalam skala seratus, kemudian nilai aktivitas siswa dalam skala seratus tersebut dikategorikan dalam empat skala. Pedoman penggolongan aktivitas siswa pada model pembelajaran kooperatif tipe Jigsaw dalam pembelajaran IPS dinyatakan dengan Tabel 3 sebagai berikut.

Tabel 3. Pedoman Penggolongan Aktivitas Belajar Siswa

\begin{tabular}{cc}
\hline Aktivitas (\%) & Kriteria \\
\hline $76-100$ & Sangat Baik \\
\hline $51-75$ & Baik \\
\hline $26-50$ & Cukup Baik \\
\hline$<25$ & Kurang Baik
\end{tabular}

Sumber: (Trianto, 2007)

Skor rata-rata aktivitas siswa yang diperoleh dari perhitungan dibandingkan dengan skor penggolongan yang telah ditetapkan. Skor rata-rata aktivitas siswa dianalisis dengan rumus:

$\overline{\mathrm{X}}=\frac{\Sigma \mathrm{X}}{N}$

Dimana :

$\overline{\mathrm{X}} \quad=$ skor rata-rata aktivitas siswa.

$\sum \mathrm{X} \quad=$ jumlah seluruh skor.

$\mathrm{N} \quad=$ jumlah siswa.

Kriteria keberhasilan penelitian ini adalah jika sikap siswa minimal berada pada kategori baik. 
Data mengenai hasil belajar siswa dianalisis secara kuantitatif deskriptif yang diperoleh melalui tes akhir siklus. Tes akhir siklus terdiri dari 25 soal objektif. Skor maksimum untuk soal objektif adalah 25 dan skor minimum adalah 0 . Hasil belajar siswa selanjutnya dikonversi dalam skala 100. Formulasinya adalah sebagai berikut.

$$
\begin{aligned}
& \mathrm{X}=\frac{\text { skor total }}{\text { skor maksimum }} \times 100 \\
& \quad \text { Nilai rata-rata hasil belajar siswa dihitung dengan formula sebegai berikut. } \\
& \bar{X}=\frac{\sum \mathrm{X}}{N}
\end{aligned}
$$

Keterangan:

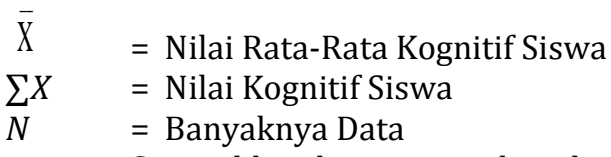

Siswa dikatakan tuntas jika nilai akhir hasil belajar siswa $\geq 68$ yang sesuai dengan KKM di kelas VII H SMP N 1 Kubu. Untuk mencari ketuntasan klasikal siswa digunakan perumusan seperti di bawah ini.

$\mathrm{KK}=\frac{\text { banyaknya siswa yang tuntas }}{\text { banyaknya siswa yang ikut tes }} \times 100 \%$

Penentuan Kategori untuk hasil belajar siswa menggunakan penilaian acuan patokan (PAP). Skor total yang diperoleh siswa dikonversi ke dalam skala 100. Seluruh hasil analisis data ini kemudian dibandingkan dengan kriteria keberhasilan penelitian ini.

Tabel 4. Kriteria Penggolongan Hasil Belajar Siswa

\begin{tabular}{cc}
\hline Kriteria & Kategori \\
\hline $85-100$ & Amat baik \\
\hline $79-84$ & Baik \\
\hline $68-78$ & Cukup \\
\hline $0-67$ & Kurang \\
\hline
\end{tabular}

\section{Hasil dan pembahasan}

Berdasarkan tindakan yang telah dilaksanakan diperoleh hasil atau data yang selanjutnya dievaluasi untuk megukur keberhasilan Penelitian Tindakan Kelas (PTK) Kolaboratif. Hasil tes menganalisis aktivitas dan hasil belajar siswa kelas VII H di SMP N 1 Kubu mengalami peningkatan setelah diterapkannya model pembelajaran kooperatif tipe Jigsaw. Model pembelajaran kooperatif tipe Jigsaw dapat diaplikasikan dalam pembelajaran IPS di kelas VII H SMP N 1 Kubu. Hal ini dapat dibuktikan dalam penilaian APKCG, pembelajaran yang dilakukan dinyatakan amat baik.

Perkembangan hasil penelitian antara siklus I dan siklus II dapat dilihat kembali pada aktivitas belajar siswa selama siklus I dan siklus II, perbandingan hasil penelitian ini bertujuan untuk mengetahui keberhasilan penelitian. Setiap siklus data yang diperolehdibandingkan untuk mengetahui tingkat keberhasilan penelitian yang telah dilaksanakan. Nilai rata-rata aktivitas belajar siswa-siswa meningkat dari 79,08 dengan kategori cukup pada siklus I menjadi 87,38 dengan kategori aktif pada siklus II. Hal ini mengindikasikan terjadi peningkatan aktivitas belajar siswa dari siklus I ke siklus II. Hasil pada siklus II sudah sesuai dengan kriteria keberhasilan tindakan yaitu aktivitas belajar siswa berada pada kategori aktif. Berdasarkan hasil tersebut, dapat disimpulkan bahwa implementasi model pembelajaran kooperatif tipe Jigsaw dapat meningkatkan aktivitas belajar siswa. 


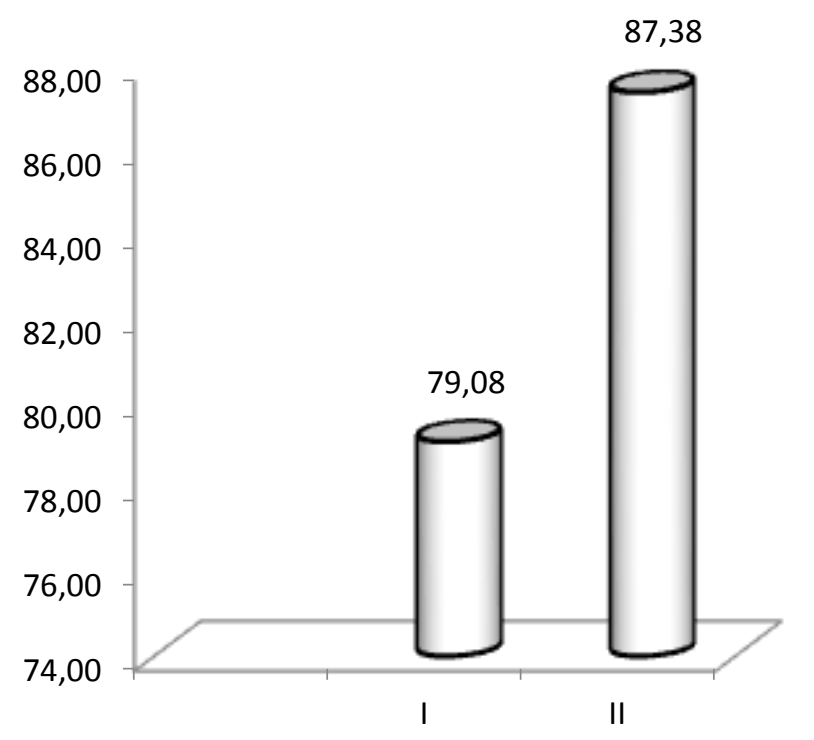

Gambar 2. Perbandingan Nilai Rata-rata Aktivitas Belajar

Nilai rata-rata hasil hasil belajar siswa diawal pembelajaran 60,00 dengan ketuntasan klasikal 44,44\%, pada siklus I menjadi 65,67 dengan ketuntasan klasikal 53,33\%. Pada siklus II rata-rata hasil belajar siswa meningkat menjadi 81,17 dengan ketuntasan klasikal 86,7\%. Hal ini mengindikasikan terjadi peningkatan hasil belajar dari awal pembelajaran sampai pada siklus II. Berdasarkan hasil penelitian pada siklus II, penelitian ini dikatakan berhasil karena rata-rata hasil belajar siswa di atas 68; daya serap siswa di atas 68\%; dan ketuntasan klasikal siswa diatas 85\%. Berdasarkan hasil tersebut dapat disimpulkan bahwa implementasi model pembelajaran kooperatif tipe Jigsaw dapat meningkatkan hasil belajar siswa.

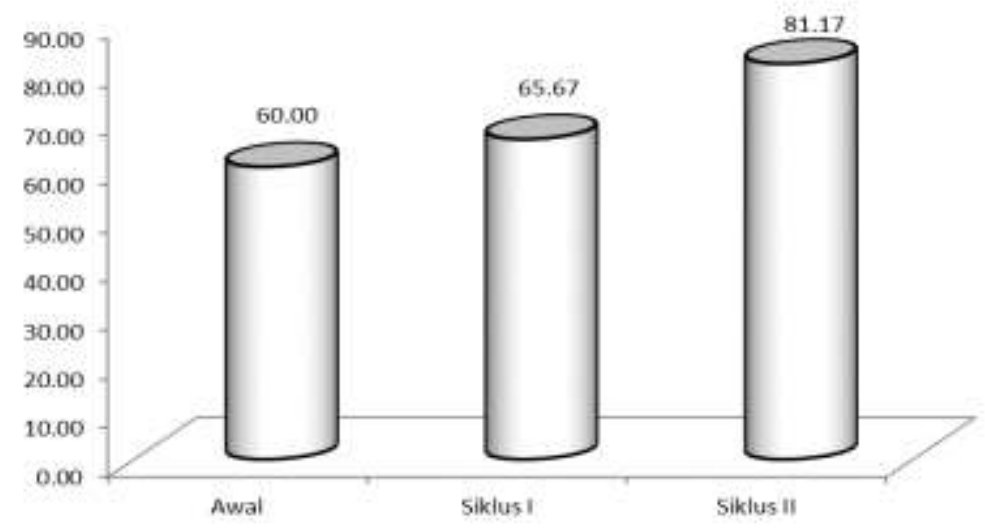

Gambar 3. Perbandingan Rata-rata Hasil Belajar Siswa

Penerapan model pembelajaran kooperatif tipe Jigsaw diawali dengan pengenalan topik yang akan dibahas oleh guru. Guru bisa menuliskan topik yang akan dipelajari di papan tulis atau dengan penayangan powerpoint dan sebagainya. Guru menanyakan kepada peserta didik apa yang mereka ketahui mengenai topik tersebut. Kegiatan sumbang saran ini dimaksudkan untuk mengaktifkan skema atau struktur kognitif peserta didik agar lebih siap menghadapi kegiatan pelajaran yang baru. Pengaplikasian model pembelajaran kooperatif tipe Jigsaw dmulai dari guru membagi kelas menjadi kelompok-kelompok kecil. Jumlah kelompok bergantung pada jumlah konsep yang terdapat pada topik yang dipelajari atau sering disebut dengan kelompok asal. Setelah kelompok asal terbentuk, guru membagikan teks kepada tiap-tiap kelompok. Setiap orang pada setiap kelompok bertanggung jawab mempelajari materi teks yang diberikan oleh guru. Sesi berikutnya membentuk kelompok ahli, kelompok ini berasal dari masing-masing kelompok asal. Hal terpenting adalah disetiap kelompok ahli ada anggota dari kelompok asal yang berbeda-beda. Secara sederhana pembentukan kelompok Jigsaw dapat digambarkan sebagai berikut. 


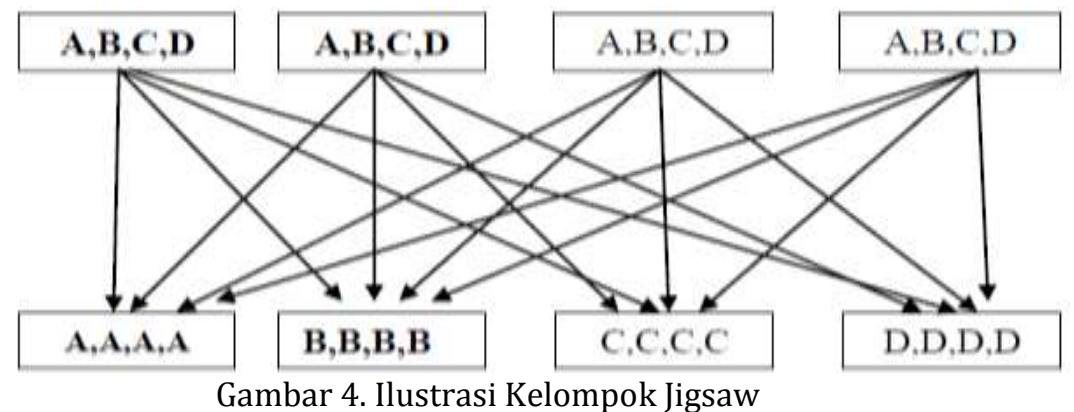

Setelah terbentuk kelompok ahli, berikan kesempatan pada mereka berdiskusi. Melalui diskusi dikelompok ahli diharapkan mereka memahami topik yang diberikan oleh guru. Selanjutnya mereka kembali ke kelompok asal. Setelah mereka kembali ke kelompok asal berikan kesempatan untuk mereka berdiskusi. Kegiatan ini merupakan refleksi terhadap pengetahuan yang telah mereka dapatkan dari hasil berdiskusi di kelompok ahli. Sebelum pembelajaran diakhiri, diskusi dengan seluruh kelas perlu dilakukan. Selanjutnya guru menutup pembelajaran dengan memberikan review terhadap topik yang telah diberikan.

Pembelajaran IPS dengan diaplikasikannya model pembelajaran kooperatif tipe Jigsaw dapat menggali potensi siswa untuk berpikir kritis, bebas mengembangkan gagasan-gagasannya serta memberi pengalaman langsung sehingga perolehan belajar tidak bersifat verbal semata, melainkan mampu memberi pengalaman langsung yang bersifat konkret. Dalam pembelajaran kooperatif tipe Jigsaw ini siswa dituntut memiliki tenggang rasa serta mau menghargai pendapat orang lain. Model pembelajaran kooperatif tipe Jigsaw menjadikan siswa dapat saling berinteraksi dan saling memunculkan strategistrategi pemecahan masalah yang efektif. Penerapan model pembelajaran kooperatif tipe Jigsaw berbeda dengan belajar kelompok biasa, karena pada pembelajaran ini siswa tidak hanya bertanggung jawab pada dirinya sendiri tetapi juga bertanggung jawab pada kelompoknya. Pembelajaran kooperatif tipe Jigsaw memberi lingkungan belajar dimana siswa bekerja sama dalam kelompok kecil yang kemampuannya berbeda di dalam menyelesaikan tugas-tugas akademik. Di dalam diskusi inilah pengetahuan yang didapatkan oleh masing-masing siswa melalui pengamatan disatukan untuk memecahkan permasalahanpermasalahan yang diajukan oleh guru. Dengan demikian model pembelajaran kooperatif tipe Jigsaw secara efektif akan dapat meningkatkan aktivitas dan hasil belajar dalam mata pelajaran IPS.

Data yang diperoleh dalam penelitian ini adalah data dari hasil observasi baik terhadap siswa maupun terhadap guru. Hasil tes menganalisis aktivitas dan hasil belajar siswa kelas VII H di SMP N 1 Kubu mengalami peningkatan setelah diterapkannya model pembelajaran kooperatif tipe Jigsaw. Sehingga model pembelajaran kooperatif tipe Jigsaw dapat diaplikasikan dalam pembelajaran IPS di kelas VII H SMP N 1 Kubu. Hal ini dapat dibuktikan dalam penilaian APKCG. Berdasarkan hasil penelitian yang telah dilaksanakan dalam dua siklus menunjukkan terjadinya peningkatan dari siklus I ke siklus II. Hasil analisis data menunjukkan rata-rata hasil belajar IPS siswa kelas VII H pada siklus I 72 dengan kategori baik dan meningkat menjadi 92 dengan kategori amat baik pada siklus II.

Berdasarkan temuan yang diperoleh pada siklus I dan siklus II, pembahasan selajutnya lebih ditekankan pada sejumlah temuan yang dianggap menonjol dari kedua siklus yang telah dilakukan. Berdasarkan uraian yang dikemukakan dalam penyajian hasil penelitian, sejumlah temuan yang dianggap menonjol adalah sebagai berikut.

1) Diberikan waktu yang memadai kepada siswa untuk berlatih sebelum melakukan unjuk kerja di depan kelas dengan pengawasan guru dapat meningkatkan hasil belajar siswa.

2) Memberikan kesempatan kepada siswa untuk berkomunikasi saat mendemontrasikan tugas-tugas di depan kelas sehingga membuat siswa lebih baik dari segi keberanian menyampaikan pendapat.

Model pembelajaran kooperatif tipe Jigsaw yang ditempuh guru dengan peneliti betul-betul efektif. Selain itu, pertanyaan-pertanyaan yang dirancang oleh guru sedemikian rupa telah mampu menggiring siswa untuk memahami materi yang telah disampaikan. Melalui penerapan model ini guru membelajarkan siswanya dengan beberapa keterampilan yang didemontrasikan kepada siswa oleh guru. Hal tersebut menjadikan pembelajaran lebih bermakna bagi siswa. Dengan disertai diskusi dan pertanyaan-pertanyaan dari guru atau siswa membuat siswa aktif dan bergairah dalam belajar.

Secara teoritis hasil penelitian ini didukung oleh Rusman (2012: 9) yang mengemukakan bahwa manfaat menggunakan model pembelajaran kooperatif tipe Jigsaw adalah mendorong siswa untuk mendengarkan, terlibat aktif dan berempati dengan memberikan kesempatan kepada anggota kelompok sebagai bagian penting dalam kegiatan akademik. Anggota kelompok harus bekerjasama sebagai satu tim 
untuk mencapai tujuan bersama, setiap orang bergantung kepada orang lain untuk mendapatkan hasil belajar yang maksimal. Hasil penelitian didukung oleh penelitian Riah (2015: 9) yang menyatakan bahwa Penerapan strategi Jigsaw pada mata pelajaran Ilmu Pengetahuan Sosial (IPS) dengan materi bentuk muka bumi dan aktivitas penduduk di Indonesia untuk siswa kelas VII SMP Muhammadiyah 10 Surakarta Tahun Ajaran 2014/2015.

Aspek aktivitas belajar siswa diperoleh dengan menggunakan pedoman observasi yang dilakukan pada setiap pertemuan dimasing-masing siklus. Berdasarkan hasil penelitian diperoleh bahwa nilai ratarata aktivitas belajar siswa pada siklus I 79.08 dengan kategori cukup menjadi 87,38 dengan kategori aktif pada siklus II. Hal ini mengindikasikan terjadi peningkatan aktivitas belajar siswa. Hasil pada siklus II sudah sesuai dengan kriteria keberhasilan tindakan yaitu aktivitas belajar siswa berada pada kategori aktif.

Berdasarkan temuan yang diperoleh pada siklus I dan siklus II, pembahasan selajutnya lebih ditekankan pada sejumlah temuan yang dianggap menonjol dari kedua siklus yang telah dilakukan. Berdasarkan uraian yang dikemukakan dalam penyajian hasil penelitian, sejumlah temuan yang dianggap menonjol adalah sebagai berikut.

1) Siswa sangat aktif bertanya kepada kelompok yang persentasi.

2) Siswa berani menyampaikan pendapat walau berbeda dengan teman yang lain.

Model pembelajaran kooperatif tipe Jigsaw yang ditempuh guru dengan peneliti betul-betul efektif. Selain itu, pertanyaan-pertanyaan yang dirancang oleh guru sedemikian rupa telah mampu menggiring siswa untuk memahami materi yang telah disampaikan. Melalui penerapan model ini siswa lebih aktif dalam melaksanakan proses pembelajaran. Hal tersebut menjadikan pembelajaran lebih bermakna bagi siswa. Dengan disertai diskusi dan pertanyaan-pertanyaan dari guru atau siswa membuat siswa aktif dan bergairah dalam belajar.

Secara teoritis hasil penelitian ini didukung oleh Isjoni, (2010:77) yang mengemukakan bahwa model pembelajaran kooperatif tipe Jigsaw mampu mendorong siswa untuk aktif. Hasil penelitian ini didukung oleh penelitian Saifi (2011: 70) yang menyatakan bahwa pembelajaran cooperative tipe Jigsaw untuk meningkatkan aktivitas dan prestasi belajar IPS siswa kelas IX .A di SMPN 12 Kotabumi Lampung Utara tp. 2010/2011.

Tes hasil belajar yang dikembangkan memuat 25 butir soal. Rata-rata hasil belajar siswa meningkat dari 60,00 dengan ketuntasan klasikal 44,44\% diawal pembelajaran, pada siklus I menjadi 65,67 dengan ketuntasan klasikal 53,33\%, pada siklus II meningkat mnjadi 81,17 dengan ketuntasan klasikal 86,7\%. Hal ini mengindikasikan terjadi peningkatan hasil belajar. Berdasarkan hasil penelitian pada siklus II, penelitian ini dikatakan berhasil karena rata-rata hasil belajar siswa di atas 68. Daya serap siswa di atas $68 \%$ dan ketuntasan klasikal siswa di atas $85 \%$.

Berdasarkan temuan yang diperoleh pada siklus I dan siklus II, pembahasan selajutnya lebih ditekankan pada sejumlah temuan yang dianggap menonjol dari kedua siklus yang telah dilakukan. Berdasarkan uraian yang dikemukakan dalam penyajian hasil penelitian, sejumlah temuan yang dianggap menonjol adalah sebagai berikut.

1) Siswa sangat atusias dalam mengikuti peroses pembelajaran di kelas, pada akhir pelajaran siswa mampu menyimpulkan materi yang dibahas ini menunjukan bahwa proses belajar mengajar di kelas sudah sesuai dengan skenario yang diharapkan.

2) Setiap petemuan menunjukan telah terjadi peningkatan jumlah siswa yang tuntas.

Model pembelajaran kooperatif tipe Jigsaw yang ditempuh guru dengan peneliti betul-betul efektif. Selain itu, pertanyaan-pertanyaan yang dirancang oleh guru sedemikian rupa telah mampu menggiring siswa untuk memahami materi yang telah disampaikan. Melalui penerapan model ini mebuat siswa lebih mengerti dengan materi yang dijelaskan dan menjadikan pembelajaran lebih bermakna bagi siswa. Dengan disertai diskusi dan pertanyaan-pertanyaan dari guru atau siswa membuat siswa aktif dan bergairah dalam belajar.

Secara teoritis hasil penelitian ini didukung oleh Rusman (2010:219) yang menyatakan bahwa model pembelajaran kooperatif tipe Jigsaw menunjukkan bahwa interaksi kooperatif di dalamnya memiliki berbagai pengaruh positif terhadap siswa. Pengaruh tersebut antara lain (1) meningkatkan hasil belajar, (2) meningkatkan daya ingat, (3) menumbuhkan motivasi intrinsik, (4) meningkatkan sikap positif siswa terhadap sekolah, (5) meningkatkan sikap positif siswa terhadap guru, (6) meningkatkan perilaku penyesuaian sosial, dan (7) meningkatkan keterampilan bergotong royong. Hasil penelitian didukung oleh penelitian Juliastuti (2016:137) yang menyatakan bahwa penggunaan metode teknik Jigsaw dalam upaya meningkatkan prestasi belajar IPS peserta didik kelas 1X.F SMPN 33 Surabaya materi benua dan samudra di bumi. 
Penekanan pada motivasi dan kebiasaan belajar juga berpengaruh terhadap hasil belajar siswa. Seperti yang dikemukakan oleh Sharah (2018) bahwa siswa yang telah menyiapkan alat, mental, dan fisiknya sebelum berangkat ke sekolah, jika dibiasakan akan menyebabkan siswa terhindar dari kehilangan konsentrasi belajar. Akibatnya siswa membiasakan diri untuk selalu konsentrasi saat belajar, meskipun jam pelajaran yang terakhir. Akan tetapi, jika siswa tidak menyiapkan alat, mental, dan fisik sebelum ke sekolah, kemungkinan siswa tersebut akan sulit konsentrasi saat belajar atau bisa jadi tugas yang seharusnya dikumpulkan tertinggal di rumah, karena tidak dipersiapkan terlebih dahulu. Latief (2014) dalam Munzadi (2018) mengemukakan bahwa dalam Proses pembelajaran Geografi (IPS), seorang guru memiliki peran penting dalam menyampaikan informasi, melatih keterampilan dan membimbing belajar siswa sehingga para guru dituntut memiliki kualifikasi dan kompetensi tertentu, agar proses belajar dan pembelajaran dapat berlangsung efektif dan efisien. Siswa membutuhkan sumber motivasi sebagai dorongan bagi mereka untuk memacu semangat siswa dalam mengikuti kegiatan belajar mengajar. Berkaitan dengan sumber motivasi, guru merupakan salah satu sumber motivasi utama bagi siswa dalam proses belajar mengajar (Simanjuntak, 2019). Selain itu jumlah siswa juga dikatakan berpengaruh terhadap hasil belajar siswa, seperti penelitian Artini (2019) menemukan bahwa hasil belajar siswa tinggi pada rombongan atau kelas belajar dengan jumlah sedikit begitupula sebaliknya.

\section{Simpulan dan saran}

Berdasarkan hasil penelitian dan pembahasan yang telah dipaparkan pada bab sebelumnya, maka dapat disimpulkan beberapa hal sebagai berikut. Penerapan model pembelajaran kooperatif tipe Jigsaw dalam pembelajaran IPS di kelas VII H dapat meningkatkan aktivitas belajar dan hasil belajar siswa. Model pembelajaran kooperatif tipe Jigsaw dapat merubah suasana belajar lebih efektif dan menyebabkan siswa menjadi lebih aktif mencari dan menggali berbagai informasi mengenai materi yang dijelaskan. Penerapan model pembelajaran kooperatif tipe Jigsaw dapat meningkatkan aktivitas belajar IPS siswa kelas VII H SMP Negeri 1 Kubu. Berdasarkan hasil penelitian diperoleh bahwa nilai rata-rata aktivitas belajar siswameningkat dari 79,08dengan kategori cukuppada siklus I menjadi 87,38dengan kategori aktif pada siklus II. Hal ini mengindikasikan terjadi peningkatan aktivitas belajar siswa dari siklus I ke siklus II. Hasil pada siklus II sudah sesuai dengan kriteria keberhasilan tindakan yaitu aktivitas belajar siswa berada pada kategori aktif. Penerapan model pembelajaran kooperatif tipe Jigsaw dapat meningkatkan hasil belajar IPS siswa kelas VII H SMP Negeri 1 Kubu. Rata-rata hasil belajar siswa meningkat dari 60,00 dengan ketuntasan klasikal 44,44\% diawal pembelajaran, pada siklus I menjadi 65,67dengan ketuntasan klasikal 53,33\%. Pada siklus II rata-rata hasil belajar meningkat menjadi 81,17dengan ketuntasan klasikal $86,7 \%$. Hal ini mengindikasi terjadinya peningkatan hasil belajar dari siklus I ke siklus II.

Berdasarkan hasil penelitian dan pembahasan telah dilakukansertatemuan-temuan yang diperoleh selama penelitian, maka dapat diajukan beberapa saran guna meningkatkan kualitas pembelajaran IPS kedepannya sebagai berikut. Implementasi model pembelajaran kooperatif tipe Jigsaw dapat digunakan sebagai salah satu alternatif model pembelajaran dalam upaya meningkatkan aktivitas belajar dan hasil belajar siswa pada pembelajaran IPS. Saran kepada guru pada umumnya agar dapat mengembangkan model pembelajaran ini pada pokok bahasan lain, bahkan dapat mengkolaborasikan model pembelajaran kooperatif lainnya, sehingga dapat memberikan suasana belajar baru yang dapat memotivasi siswa agar tertarik dengan pembelajaran IPS. Pemberian LKS dalam mengimplementasikan model pembelajaran sebaiknya dilakukan pada pertemuan sebelumnya. Hal ini dapat memberikan kesempatan kepada siswa lebih banyak dalam memahami masalah yang ada dalam LKS. Siswa akan lebih mudah dalam membuat hipotesis karena siswa dapat mengetahui dan mempelajari lebih awal permasalahan yang akan dihadapi. Guru harus mampu membentuk keheterogenan anggota dalamkelompok belajar, terutama dari segi kemampuan dalam mengimplementasikan kooperatif tipe Jigsaw. Keheterogenan anggota kelompok ini berfungsi untuk memberikan motivasi belajar kepada siswa, baik yang memiliki kemampuan lebih atau kurang. Siswa yang memiliki kemampuan lebih akan menjadi tutor bagi siswa masih kurang pengetahuannya. Hal tersebut dapat menyebabkan terjadi interaksi dari teman sebaya yang memiliki orientasi yang sama untuk memajukan kelompoknya, sehingga siswa dengan kemampuan yang lebih akan dapat memantapkan pengetahuannya tersebut, sedangkan pada siswa yang berkemampuan rendah akan dapat belajar lebih banyak dari teman sebayanya tersebut. 


\section{Daftar Rujukan}

Apriliawati. (2011). Penerapan Strategi Motivasi ARCH Dalam Pembelajaran Kooperatif Tipe STAD. Surabaya: UNESA.

Arikunto, S. (1993). Prosedur Penelitian Suatu Pendekatan Praktik. Jakarta: Rineka Cipta.

Artini, N. S. dan I. B. M. A. (2019). Studi Tentang Komponen Pembelajaran Geografi Sma/Ma Antara Wilayah Perkotaan Dan Perdesaan Di Kabupaten Buleleng Serta Implikasinya Terhadap Hasil Belajar Siswa. Jurnal Jurusan Pendidikan Geografi Undiksha, 7(1), 35-43.

Isjoni. (2010). Cooperative Learning Efektifitas Pembelajaran Kelompok. Bandung: Alfabeta.

Juliastuti. (2016). Penggunaan Metode Teknik Jigsaw Dalam Upaya Meningkatkan Prestasi Belajar IPS Peserta Didik Kelas IX.F SMP 33 Surabaya Materi Benua Dan Samudra Di Bumi. Jurnal Pendidikan, 1(2), 137.

Moedjiono dan Moh Dimyati. (1992). Strategi Belajar Mengajar. Jakarta: Depdikbud Derektorat Jendral Pendidikan Tinggi Proyek Pembinaan Tenaga Kependidikan.

Munirah. (2015). Sistem Pendidikan Di Indonesia. Jurnal Auladuna. Jurnal Auladuna, 2(2), 238.

Munzadi, M. (2018). Pengaruh Blended Learning Berbasis Rotation Model Terhadap Motivasi Dan Hasil Belajar Geografi Siswa Ma Matholiul Anwar Lamongan. Jurnal Jurusan Pendidikan Geografi Undiksha, 6(3), 125-132.

Riah, Q. F. (2015). Penerapan Strategi Jigsaw Pada Mata Pelajaran Ilmu Pengetahuan Sosial (IPS) Dengan Materi Bentuk Muka Bumi Dan Aktivitas Penduduk Di Indonesia Untuk Siswa Kelas VII SMP Muhammadiyah 10 Surakarta Tahun Ajaran 2014/2015. Universitas Muhammadiyah Surakarta.

Rusman, K. (2010). Model-Model Pembelajaran. Bandung. Bandung: Mulia Mandiri Press.

Rusman, K. (2012). Model-model Pembelajaran: Mengembangkan Profesionalisme Guru. Bandung: Raja Grafindo Persada.

Saifi. (2011). Pembelajaran Cooperative Tipe Jigsaw Untuk Meningkatkan Aktivitas Dan Prestasi Belajar IPS Siswa Kelas IX.A Di SMPN 12 Kotabumi Lampung Utara Tp. 2010/2011. Universitas Lampung.

Sharah, A. dan I. B. M. A. (2018). Pengaruh Motivasi Dan Kebiasaan Belajar Terhadap Hasil Belajar Geografi Siswa Sma Negeri Di Kota Singaraja. Jurnal Jurusan Pendidikan Geografi Undiksha, 6(2), 64-74.

Simanjuntak, R. I. M. dan I. B. M. A. (2019). Studi Komparatif Variasi Kompetensi Kepribadian Guru Dengan Motivasi Belajar Siswa Pada Mata Pelajaran Ips Di Smp Negeri 2 Sawan. Jurnal Jurusan Pendidikan Geografi Undiksha, 7(2), 115-124.

Suhardjono. (2008). Penelitian Tindakan Kelas. Jakarta: PT Bumi Aksara.

Trianto. (2007). Model-Model Pembelajaran Inovatif Berorientasi Konstruktifistik. Jakarta: Prestasi Pustaka.

Trisianawati, E. (2016). Pengaruh Model Pembelajaran Kooperatif Tipe Jigsaw Terhadap Hasil Belajar Siswa Pada Materi Vektor Di Kelas X SMA Negeri 1 Sanggau Ledo. Jurnal Penelitian Fisika Dan Aplikasinya (JPFA), 6(2), 53.

Wahyudin, K. (2007). Pengantar Pendidikan. Jakarta: Universitas Jakarta. 